\title{
The Impact of Asset Quality on Profitability: A Panel Data Analysis of Domestic Commercial Banks in Sri Lanka
}

\author{
P. D. M. Sanathanee ${ }^{1}$
}

\begin{abstract}
This research attempts to determine the effects of asset quality on the banking profitability of commercial banks in Sri Lanka. This study is based on secondary data for the period 2008 to 2016, which are obtained from annual reports published by 9 commercial banks in Sri Lanka. The analysis based on panel fixed effect regression indicates that asset quality factors had a negative impact on the bank's profitability at a statistically insignificant level. This was mainly because asset quality does not solely determine the profitability of banks. Other factors such as capital adequacy, management efficiency, earnings performance and liquidity may also contribute to profitability. Based on the findings, this study recommends that improved investment assets levels and the low rate of non-performing assets needs to be realized through credit risk identification, measurement, monitoring and controlling, in order to achieve high asset quality levels. Accordingly, this study recommends that banks improve credit policy by obtaining collateral and adhering to strong credit risk assessment indicators by following post sanction risk monitoring mechanism.
\end{abstract}

Keywords: Licensed Commercial Banks, Licensed Specialised Banks, Non-Performing Loans, Gross Domestic Product

\footnotetext{
1 The auditor is currently serving as Senior Assistant Director of The Department of Bank Supervision. Corresponding email: sanathanee@cbsl.lk. The views presented in the paper are those of the author and do not necessarily indicate the views of the Central Bank of Sri Lanka.
} 


\section{Introduction}

Banks engage in financial intermediation by efficiently mobilizing public funds and disbursing to different sets of economic agents in the forms of loans and advances. This intermediation role of banks supports to carry their financial and economic activities effectively. Hence, a bank's stability in a developing economy is noteworthy as any distress could affect the development plan of the public sector as well as profit and growth motives of private sector (Rajaraman \& vasishtha, 2002).

According to Ombaba (2013), the stability of banking is a pre-requisite for economic development and resilience against financial crisis. Further, like any other business, the success of a banking business is mainly assessed based on financial performance, profitability and the quality of assets it possesses.

Assets quality refers to loan quality which associates low default risk. Nagle (1991) states that the problem of assets quality may become the future time bomb for banks. This was proved by Khalid (2012) in an empirical study based on Indian private banks. Yin (1999) referred that the deterioration of assets quality from the ignorance of loan quality by banks is one of the main causes behind the Asian Finance crisis in the early 1990s. Adhikary (2006) mentioned that lower assets quality/ non-performing loans (NPAs) reaching substantial amount may lead to bankruptcies and economic slowdowns as evidenced by the 2008 global crisis.

Considering the importance of managing the quality of assets in banks, "The Standards for Safety and Soundness" were brought in to force by the United States Federal Reserve Board in 1995, stipulating regular reporting obligation on assets quality for Board of Directors of banks in order to evaluate risk on the deformation of assets quality and to form assets quality supervision mechanism by banks to define problems that may arise on assets quality (Eze \& Ogbulu, 2016). Further, 7 of the 25 fundamental principles determined by the Basel Committee on Banking Supervision (BCBS) for effective supervision of the banking system are related to assets quality of banks and loan risk management, thereby indicating that assets quality becomes an important aspect of supervision authorities.

Due to the above aspects, it is apparent that better asset quality fosters higher profitability and reduces the cost of failure. From an economic perspective, bad quality of assets leads banks to bankruptcy, damaging the smooth functioning of the economy. This has a contagious effect when it comes to financial assets, intermediary process and financial markets due to interlinkages.

This research will assess the nature and the level of the inter-relationships between the asset quality of banks and the motive of profitability. 
Accordingly, this study focuses on the impact of asset quality factors on the profitability of commercial banks in Sri Lanka and contributes to growing literature on bank asset quality management while suggesting measures for the policy development process.

\section{Overview of the Banking Industry in Sri Lanka}

The banking sector in Sri Lanka comprises of 26 Licensed Commercial Banks (LCBs) and 6 Licensed Specialised Banks (LSBs). Both LCBs and LSBs dominate the financial market by holding $62.1 \%$ of the total assets of the financial system out of which LCBs are the major category by holding $54.3 \%$. Further, the importance of LCBs is significant when considering the magnitude of services they provide to the economy. There are 6 large domestic banks which are systematically important, representing a market share of $74 \%$ in terms of LCBs sector's assets out of the 26 LCBs.

According to the Central Bank of Sri Lanka's Annual Report 2019, the asset portfolio of the banking sector was reported at Rs. 12.5 trillion by end of 2019 and loan portfolio (65\%) represented the major component amounting to Rs. 8.1 trillion (Figure 1). Therefore, a bank's core business is built on loans that are disbursed to different segments in the economy. Hence, it is observed that the loan portfolio of banks is a significant component in the earning structure of banks which mainly accelerate the profit of banks (Figure 2).

Figure 1: Asset structure of Banks

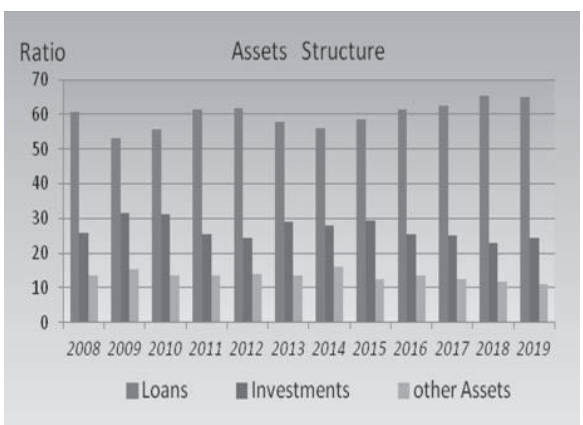

Source: Industry data (CEOs’ presentation 2019Q4)

\section{Figure 2: Income structure of Banks}

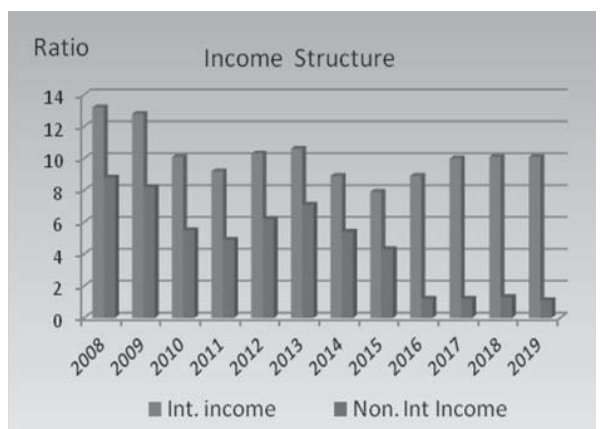

Source: Industry data (CEOs’ presentation 2019Q4) 
Figure 3: Trend in profitability and loans

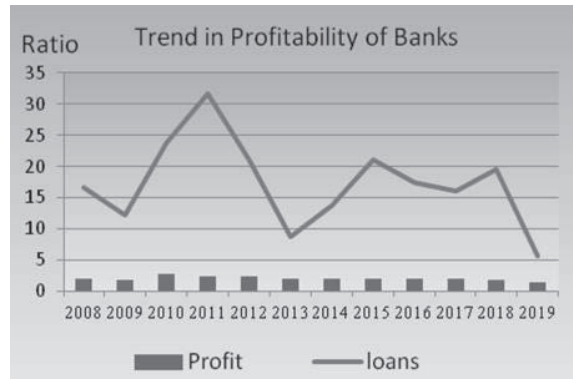

Source: Industry data (CEOs' presentation 2019Q4)

\section{Figure 4: Trend in NPAs and profitability}

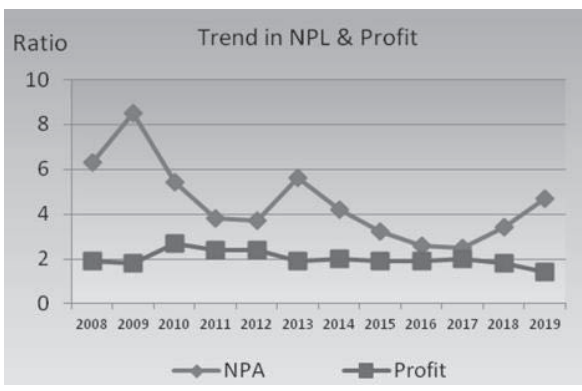

Source: Industry data (CEOs' presentation 2019Q4)

However, as depicted in Figure 3, even though the loan portfolio of banks mainly accelerates its profits, simultaneous change in profit (profit after tax) had not taken place over the period compared to the change reported in the loan portfolio. Further, an increase in bank profitability shown in Figure 4 is comparatively low when compared with the decrease reported in NPAs.

\section{Significance of the Study}

The findings of this study will enable bank managers to formulate strategies in order to enhance better management of their loans/assets portfolio in line with their investment and growth strategies and maximization of wealth goals.

From the perspective of regulators, this study will be useful in policymaking relating to the commercial banks' asset quality management which will result in further protecting of depositors' funds while enhancing the bank's financial performance and economic stability.

Further, this research will contribute to the existing finance related literature and further studies in the field of credit and finance.

\section{Literature Review}

Bank asset quality is a significant factor in banking research as high NPAs leads banks to bankruptcy. However, asset quality and bank efficiency are non-related because operating personnel are not normally involved in the selection and supervision of borrowers. Banks on 
the edge of bankruptcy appear to have a high NPA ratio as well as low cost efficiency. Some studies show that the level of liquidated banks is high due to inefficient credit risk management Khalid (2012), Michael et al (2006), Ombaba (2013).

Streeter (2000) reports that asset quality management was considered one of the major management problems in banks in 2001 based on the self-administrated questionnaires served to the members of American Bankers Association Board which consists of one third of bank officials from all US Banks; the result of the above survey sufficiently proves that asset quality management is a common issue for bankers in practice. Similarly, G Miller (CEO of America Corp.) considered asset quality to be the second most important management issue and formed a task force specifically to handle rising bad assets.

De Yong (1997) observes that a bank's ranking is significantly affected by asset quality. Bank asset quality is always an important element for the evaluations of bank rating and management. Marshall (1999) also found that one of the main features the best community banks hold is good quality assets. Given that bad quality assets can prompt to downgrade a bank's rating, it becomes more difficult to earn depositors' trust, and such banks can therefore only attract deposits by offering a higher deposit rate.

According to Achou and Tenguh (2008), NPAs have an inverse relationship with bank profits. Hence, they suggest prudential credit risk management and safeguarding the assets of banks to protect investor's interest.

Kosmidou (2008) applied a linear regression model on 23 Greek commercial banks for the period of 1990 to 2002, using Return on Assets (ROA) and the ratio of loan loss reserve to gross loans to proxy profitability and asset quality respectively. The results showed a negative significant impact of asset quality to bank profitability. This was in line with the theory that increased exposure to credit risk is normally associated with decreased firm profitability.

Rajaraman, Bhaumik and Bhatia (1999) have explained the variations in NPAs across Indian banks through differences in operating efficiency, solvency and regional concentration. Rajaraman and Vasishstha (2002) in their empirical study have shown that a significant bivariate relationship exists between NPAs of public sector banks and inefficiency problems. Khalid (2012) examines the relationship between assets quality and operating performance of Indian private commercial banking industry. The analytical model showed that when a bank's assets quality become worse, it takes more resources for a bank to conduct non-value added credit receiving activities, which leads to poor performance. Using actual data of sample banks from 2006 to 2011, the bank's operating efficiency scores were obtained through regression which showed that assets quality and profitability were negatively related. He also explains that due to the large number of banks in India which resulted in dropping profit level, rising risk appetite and assets quality deterioration caused by pernicious competition, it led to bank runs. 
Not only does a bank's assets quality affect its financial condition and operating results, but it also affects the soundness of the entire banking system.

Kwan and Eisenbis (1997) examined the relationship between problem loans and bank efficiency by employing the Granger Causality Technique and found that a high level of problem loans causes banks to increase spending on monitoring. Similar results were observed by Abata (2014) by studying the relationship among loan loss ratio, investments to assets ratio and return on assets of banks based on the financial information of the six largest banks in Nigeria. The research found a significant positive relationship between loans to asset ratio and bank profit.

Hempel et al (1994) observed that banks with high loan growth often assume more risk as credit analysis and review procedures are less rigorous. However, returns are high in such loans indicating a risk and return trade-off.

Sensitivity of bank profitability to macroeconomic variables has assumed greater importance in the wake of financial crisis. In general, increased economic growth leads to an increased demand for credit which allows them to increase their charges thereby increasing profitability. Demirguc-Kunt et al (2001) and Biker et al (2002) found a correlation between economic business cycle and credit growth. Demirguc-Kunt and Huizinga (2000) and Athanasoglou et al (2008) point towards a positive relationship between GDP growth and bank profit.

The effect of inflation can be substantial on the solvency of banks. If inflation is fully anticipated and interest rates are adjusted accordingly, then a positive impact on profitability will result. Alternatively, unexpected rises in inflation cause cash flow difficulties for borrowers, which can lead to premature termination of loan arrangement and precipitate loan losses. Guru et al. (2002) and Jiang et al. (2003) found that a high inflation rate leads to higher bank profitability. The study of Abreu and Mendes (2000) presented a negative coefficient for the inflation variable in European countries. Further, Demirguc-Kunt and Huizinga (2000) note that banks in developing countries tend to be less profitable in inflationary environments.

\section{Research Problem}

As per the recent financial data of LCBs highlighted in the paragraph on overview of the banking sector in Sri Lanka, less fluctuation in profitability was identified when compared to the high volatility in NPAs.

These results slightly deviate from the established findings of the empirical researches by Kosmidou (2008), Achous \& Tenguh (2008), Rajaraman \& vasishstha (2002) and Klein (2013) that present a significant strong negative relationship between the lower assets quality and bank profitability. Therefore, the relationship between the assets quality and profitability is worth being studied. 
Based on the literature review, it is clear that only a few studies have been conducted to measure the impact of asset quality on banking profitability using both bank internal factors and macroeconomic factors particularly in the context of developing countries. Similarly, there are very few studies published about the Sri Lankan context due to data unavailability. This is perhaps due to the lack of sufficient published, disaggregated information on the micro management of NPAs and the nature of default.

Considering the gaps highlighted above, this paper derives the following research question:

What is the impact of assets quality factors on bank's profitability in the commercial banks of Sri Lanka?

Based on the literature review of this study, the null-hypotheses formulated are as follows:

$\mathrm{H}_{0}$ : Gross NPA to Gross Advances ratio, Net NPA to Net Advances ratio, Loans to Total Assets Ratio, Provision Coverage Ratio, GDP rate and Inflation rate do not have relationships with bank profitability.

$\mathrm{H}_{1}$ : Gross NPA to Gross Advances ratio, Net NPA to Net Advances ratio, Loans to Total Assets Ratio, Provision Coverage Ratio, GDP rate and Inflation rate have relationships with bank profitability.

\section{Data, Model and Methodology}

\subsection{Data}

Business models of banks are different in LCBs and LSBs in terms of the ownership structure; e.g., some government-owned banks mainly focus on housing financing, and some are fully dependent on SME financing. Therefore, these specialized banks were excluded from the sample in order to eliminate sample bias and inconsistencies.

Accordingly, this study is limited to include the largest domestic commercial banks that have similar business models. Those are namely, Hatton National Bank, Commercial Bank, Sampath Bank, Seylan Bank, Nations Trust Bank, National Development Bank, Pan Asia Banking Corporation, DFCC Vardhana Bank and Union Bank. State banks and small private banks were excluded from the sample since data of these banks may generate spurious results due to their exceptional business models.

Considering difficulty in accessing and obtaining information for a long period of time, this study considers financial information for the period 2008Q1 to 2016Q4 in order to derive a best-fitted estimation using 320 observations. 


\section{Data Sources}

Data of banks were mainly obtained from publications such as their annual reports and websites. Macroeconomic variables are retrieved from annual reports published by the Central Bank of Sri Lanka and the publications of the Census and Statistics Department.

\subsection{Variables}

The literature review on banks' profitability studies suggests that bank profitability is determined by internal and external factors. Hence, this study considers profitability as the dependent variable, and asset quality variables as independent variables. Independent variables are divided into two sub categories such as bank internal asset quality factors and external macro-economic factors.

\section{Dependent Variables}

In this study, bank profitability is measured by Return on Assets (ROA) ${ }^{1}$ and Return on Equity (ROE)

ROA: This ratio measures the percentage of profits earned per rupee of assets and thus is a measure of the efficiency of the company in generating profits on its assets $(\mathrm{ROA}=\mathrm{Net}$ Profit/ Total Assets).

ROE: This ratio is defined as net profits expressed as a percentage of shareholder equity and reserves $(\mathrm{ROE}=$ Net Profit/ Shareholders' Fund). Accordingly, the mean of ROA and ROE has been taken as the dependent variable.

\section{Independent Variables}

Internal assets quality factors: As the bank internal asset quality factors, Gross NPA to Gross Advances (GNGA), Net NPA to Net Advances (NNNA), Net NPA to Total Assets (NNTA), Loans to total Assets (LTA) and Provision Coverage Ratio (PCR) will be presumed.

$\mathrm{GNGA}^{2}$ : This ratio measures the quality of assets in a situation, where the management has not provided for loss on NPA. Gross NPA is measured as a percentage of Gross Advances (GNGA=Gross NPA/ Gross Advances).

$\mathrm{NNNA}^{3}$ : This ratio is the most standard measure of asset quality and measures the Net NPA as a percentage of Net Advances (NNNA = Net NPA/ Net Advances).

1 Kosmidou (2008), Abata (2014) considered ROA and ROE as key ratios for measuring profitability of banks.

2 Khalid (2012), Rajaraman and Vasishsta (2002) in their empirical studies have shown a negative significant relationship between NPA and efficiency parameters.

3 Rajaraman and Vasishsta (2002) used this proxy to determine efficiency of assets quality and negative relationship found. 
NNTA $^{4}$ : This ratio indicates the efficiency of the bank in assessing credit risk and to an extent recovering the debts (NNTA $=$ Net NPA / Total Assets).

LTA $^{5}$ : This ratio explains a bank's primary objective of lending. A high ratio indicates a bank's willingness to interest bearing income sources. Loans to Assets ratio is measured as total Loans as a percentage of total Assets of the bank (LTA= Total Loans / Total Assets).

$\mathrm{PCR}^{6}$ : Provision coverage ratio is an indication of bank credit risk management and is measured by the provisions made by banks as a percentage of total NPA (PCR=provision made/ Total NPA).

External Assets Quality Factors: GDP growth rate (GDP) and Inflation rate (IR) are used as macroeconomic factors which are presumed to have an impact on bank profitability.

$\mathrm{GDP}^{7}$ : GDP indicates overall growth in economy and it is expected to have a positive relationship with a bank's profits since economic growth would increase bank activity such as increase in a bank's funding sources and loan growth.

$\mathrm{IR}^{8}$ : This illustrates overall percentage increase in the Colombo Consumer Price Index for goods and services of the economy. The relationship between a bank's profits and inflation is ambiguous since an increase in inflation would increase loan interest rates and enhance profits as well as increase the financing cost and reduce bank loan recoveries.

Description of variables and its relationships are elaborated in Table 1.

4 Rajaraman and Vasishsta (2002).

5 Abata (2014) studied the relationship between loans to assets ratio and bank profitability. A positive relationship found.

6 Christos K. Staikouras (1998) used provision coverage ratio as an independent variable and found a negative relationship on bank performace.

7 Demirguc Kunt et al (2001), Biker et al (2002) introduced economic variables such as GDP and Inflation to their studies to find out the sensitivity of bank profit for economic changes and found high positive correlations.

8 Refer above 7. 
Table 1: Description of Variables

\begin{tabular}{|c|c|c|c|c|}
\hline Variables & Notation & Description & $\begin{array}{l}\text { Previous } \\
\text { studies } \\
\text { findings }\end{array}$ & $\begin{array}{l}\text { Expected } \\
\text { Relationship }\end{array}$ \\
\hline $\begin{array}{l}\text { Dependent } \\
\text { (Profitability) } \\
\text { Independent (Asse }\end{array}$ & $\begin{array}{l}\text { ROA } \\
\text { ROE }\end{array}$ & $\begin{array}{l}\text { Return on average total assets } \\
\text { (ROA =Net Profit/ Total Assets) } \\
\text { Return on shareholders' funds } \\
\text { (ROE = Net Profit/ Shareholders' Fund). }\end{array}$ & & \\
\hline \multicolumn{5}{|l|}{ Internal Factors: } \\
\hline $\begin{array}{l}\text { Gross NPA to } \\
\text { Gross Advance } \\
\text { (GNGA=Gross } \\
\text { NPA/ Gross } \\
\text { Advances) }\end{array}$ & GNGA & $\begin{array}{l}\text { Lower ratio indicates better quality of assets. } \\
\text { Low GNGA of banks increases interest } \\
\text { income and decrease customer default cost. } \\
\text { Hence a negative relationship is expected } \\
\text { between profit and GNGA. }\end{array}$ & $\begin{array}{l}\text { Negative } \\
\text { significant } \\
\text { relationship }\end{array}$ & - \\
\hline $\begin{array}{l}\text { Net NPA to Net } \\
\text { Advances } \\
\text { (NNNA = Net } \\
\text { NPA/ Net } \\
\text { Advances) }\end{array}$ & NNNA & $\begin{array}{l}\text { Net NPAs are gross NPAs net of provision } \\
\text { and interest in suspense. Lower ratio } \\
\text { indicates better quality of assets and } \\
\text { contributes to enhance bank earnings while } \\
\text { reducing customer default cost. Inverse } \\
\text { relationship is expected. }\end{array}$ & $\begin{array}{l}\text { Negative } \\
\text { relationship }\end{array}$ & - \\
\hline $\begin{array}{l}\text { Net NPA to } \\
\text { Total Assets } \\
\text { (NNTA = Net } \\
\text { NPA/ Total } \\
\text { Assets) }\end{array}$ & NNTA & $\begin{array}{l}\text { Net NPAs are calculated by adjusting } \\
\text { provisions against Gross NPAs. Lower ratio } \\
\text { indicates the better performance of banks. }\end{array}$ & $\begin{array}{l}\text { Negative } \\
\text { relationship } 4\end{array}$ & - \\
\hline $\begin{array}{ll}\text { Loans } & \text { to } \\
\text { Assets } & \\
\text { (LTA }= & \text { Total } \\
\text { Loans/ } & \text { Total } \\
\text { Assets). } & \end{array}$ & LTA & $\begin{array}{l}\text { Higher the loans increase assets portfolio of } \\
\text { banks and accordingly improve bank } \\
\text { earnings and profit. A positive relationship is } \\
\text { expected. }\end{array}$ & $\begin{array}{l}\text { Positive } \\
\text { relationship }\end{array}$ & + \\
\hline $\begin{array}{l}\text { Provision } \\
\text { Coverage ratio. } \\
\text { (PCR=provision } \\
\text { made/ Total } \\
\text { NPA) }\end{array}$ & PCR & $\begin{array}{l}\text { Higher ratio indicates high level of bad assets } \\
\text { of the bank and impact to reduce profit of } \\
\text { the bank. An inverse relationship is expected. }\end{array}$ & $\begin{array}{l}\text { Negative } \\
\text { relationship }{ }^{6}\end{array}$ & - \\
\hline \multicolumn{5}{|l|}{ External Factors: } \\
\hline $\begin{array}{l}\text { GDP Growth } \\
\text { Rate }\end{array}$ & GDP & $\begin{array}{l}\text { GDP is a general index for economic } \\
\text { development. High GDP implies economic } \\
\text { growth, business expansion and better } \\
\text { quality of assets increasing bank profits. A } \\
\text { positive relationship is expected. }\end{array}$ & $\begin{array}{l}\text { Significant } \\
\text { positive } \\
\text { relationship }\end{array}$ & + \\
\hline Inflation Rate & IR & $\begin{array}{l}\text { Inflation is associated with higher costs and } \\
\text { reduces profits. Low inflation stabilizes the } \\
\text { economy and improves the profit. }\end{array}$ & $\begin{array}{l}\text { Some found } \\
\text { positive } \\
\text { relationship } \\
\text { and some } \\
\text { negative }^{8}\end{array}$ & $-/+$ \\
\hline
\end{tabular}




\subsection{Model and Methodology}

The existing literature and empirical findings suggest a linear form general model as similar studies conducted by Abata (2014), Khalid (2012), Swamy (2015) and many other researches used panel data to measure the relationship between the dependent variable and independent variable.

The primer model that was estimated by Abata (2014), Khalid (2012) and Swamy (2015) using panel techniques is;

$$
Y i t=\alpha+X i t+\delta i+\gamma t+\varepsilon i t
$$

Where Yit is the dependent variable and Xit is a $\boldsymbol{k}$-vector of regressors, and $\mathcal{E}$ it is the error terms for $i=1,2, \ldots \ldots \ldots, M$ cross-sectional units observed for dated periods $t=1,2, \ldots, T$. The $\alpha$ Parameter represents the overall constant in the model, while the $\delta i$ and $\gamma t$ represent cross-sectional effects and period specific effects (random or fixed) respectively.

Based on the above, the following specification is designed for a panel regression method of this study to analyse the determinants of profitability

$$
\begin{aligned}
Y_{i t}= & \alpha+\beta_{1}(G N G A)_{i t}+\beta_{2}(N N N A)_{i t}+\beta_{3}(N N T A)_{i t}+\beta_{4}(L T A)_{i t}+\beta_{5}(P C R)_{i t}+ \\
& \beta_{6}(G D P)_{i t}+\beta_{7}(I R)_{i t}+\delta i+\gamma t+\varepsilon_{i t}
\end{aligned}
$$

Where,

$Y_{i t}=$ Profitability (Mean of ROA and ROE) $\mathbf{i}$ for banks in year $\boldsymbol{t}$

$\alpha=$ constant. $\beta_{1}, \beta_{2}, \beta_{3}, \beta_{4}, \beta_{5}, \beta_{6}$ and $\beta_{7}$ are regression coefficients.

GNGA $=$ Gross NPA to Gross Advance

NNNA $=$ Net NPA to Net Advances

NNTA $=$ Net NPA to Total Assets

LTA $=$ Loans to Total Assets

PCR $=$ Provision Coverage Ratio

GDP $=$ GDP Rate

IR = Inflation Rate

$\delta i=$ Cross sectional effect

$\gamma t=$ Time period effect

$\varepsilon_{\mathrm{it}}=$ Error term

$\mathrm{i}=10$ banks, $\mathrm{t}=2008 \mathrm{Q} 1-2016 \mathrm{Q} 4$ 
As per similar studies of existing research literature, a Multiple Regression Model has been adopted for this study using panel data to measure the relationship among the independent and dependent variables. E-views will be used for the econometrics analysis.

\subsection{Data and Assumptions}

Panel data ${ }^{9}$ has been used for this multiple regression model as it has the advantage of providing more informative data consisting of both the cross sectional information, which captures individual variability as well as the time series information that captures dynamic adjustment.

This study estimated a Hausman's specification test as per Greene, 2003 to select whether the best model is a fixed or random effect model to estimate the multiple regression of this study (Table 2).

Accordingly; $\mathrm{H}_{0}$ : individual effects are not uncorrelated with other variables.

$\mathrm{H}_{1}$ : Ho is not true.

Table :2 Correlated Random Effects - Hausman Test

\begin{tabular}{lccc}
$\begin{array}{l}\text { Test cross-section and period random effects } \\
\text { Chi-Sq. Statistic }\end{array}$ & Chi-Sq. d.f. & Prob. \\
\hline Cross-section random & 0.971058 & 7 & 0.9953 \\
Period random & 8.506501 & 5 & 0.1304 \\
Cross-section and period random & 8.464509 & 5 & 0.1324 \\
\hline
\end{tabular}

Decision: if 0.05> Probability; Null is accepted.

As per the test values, probability values are higher than 0.05 . Therefore, the null hypothesis is rejected indicating that individual effects of the regressors of this study are uncorrelated with other variables and a Fixed Effect Model is preferred over a Random Effect Model. Hence, a fixed effect model ${ }^{10}$ is used and it is assumed that bank specific effects do not significantly vary.

9 The combination of time series with cross sections can enhance the quality and quantity of data in ways that would be impossible using only one of these two dimensions (Gujarati, 638).

10 "The slope coefficient on independent variable is the same from one entity to the next entity (Cross sections). Stock and Watson, 2003, p.289-290). 


\section{Data Analysis, Estimation and Empirical Results}

\subsection{General Behaviour of variables}

As data represent time series, the general behaviour of independent and dependent variables was tested through descriptive statistics before running the regression model. Descriptive statistics explain the central tendency of variables (Table 3). Since the sample is greater than the 30 observations, two tail tests were carried out at 5 percent significant level (Appendices).

As per Table 3 below, mean ratios of the dependent variable (Y) and other independent variables (GNGA, NNNA, NNTA, PCR, GDP and IR) considered for this study were positive at $5 \%$ and $1 \%$ significant level respectively. However, the probability value of LTA (0.47) is identified at an insignificant level. Further, the low standard deviation value of independent variables, such as GNGA, NNNA, NNTA, LTA, PCR, and IR reflected that data points of them are extremely close to the mean.

Table 3: Descriptive Statistics

\begin{tabular}{lcccccccc}
\hline \hline & $\begin{array}{c}\text { Profitability } \\
(\mathrm{Y})\end{array}$ & GNGA & NNNA & NNTA & LTA & PCR & GDP & IR \\
\hline Mean & 8.554 & 6.103 & 3.144 & 2.459 & 64.314 & 47.526 & 11165.03 & 5.334 \\
Median & 8.557 & 5.982 & 2.856 & 2.046 & 65.114 & 43.662 & -2856.00 & 5.600 \\
Maximum & 15.326 & 14.30 & 8.929 & 8.580 & 79.662 & 145.67 & 75916.00 & 9.300 \\
Minimum & 2.423 & 1.323 & -1.261 & -0.806 & 49.161 & 8.553 & 28117.00 & 0.100 \\
Std. Div. & $\mathbf{2 . 7 3 6}$ & $\mathbf{2 . 7 5 6}$ & $\mathbf{2 . 2 4 1}$ & $\mathbf{1 . 6 9 1}$ & $\mathbf{6 . 0 5 5}$ & $\mathbf{2 2 . 8 3 6}$ & $\mathbf{3 2 2 1 0 . 4 6}$ & $\mathbf{2 . 8 3 5}$ \\
Skewness & 0.109 & 0.519 & 0.644 & 0.944 & -0.155 & 1.745 & 0.66083 & -0.443 \\
Kurtosis & 2.328 & 2.796 & 3.226 & 3.796 & 2.872 & 7.364 & 2.05152 & 2.123 \\
Probability & $\mathbf{0 . 0 3 5 8}$ & $\mathbf{0 . 0 0 0 5}$ & $\mathbf{0 . 0 0 0 0}$ & $\mathbf{0 . 0 0 0 0}$ & $\mathbf{0 . 4 7 4 1}$ & $\mathbf{0 . 0 0 0 0}$ & $\mathbf{0 . 0 0 0 0}$ & $\mathbf{0 . 0 0 0 0}$ \\
\hline
\end{tabular}

\subsection{Multicolinearity}

Correlation among variables was performed to identify multicolinearity. If a correlation coefficient matrix demonstrates correlation of 0.75 or higher among the variables, there may be multicollinearity. Other statisticians suggest that correlations of 0.90 or greater may indicate multicollinearity. ${ }^{11}$

\footnotetext{
11 Wooldridge, J M., Introductory Econometrics, $4^{\text {th }}$ Edition, Chapter15.
} 
Accordingly, the correlations among independent variables of this study have been tested through a correlation matrix. Summarized results are given in Table 4 below. As per the results of the correlation matrix, correlations of all variables reported below the level of 0.75 representing a weak correlation position. Therefore, it can be concluded that proposed model does not suffer from any multicolinearity problem.

Table 4 exhibits correlation among the independent variables. Accordingly, strong negative correlation of GNGA is found between LTA, PCR and IR. Also, a weak positive relationship of GNGA is found between NNNA and NNTA, as well as NNTA over NNNA. Further, a weak negative correlation of PCR found with NNNA and NNTA.

Table 4: Correlation Matrix

\begin{tabular}{llllllll}
\hline \hline & GNGA & NNNA & NNTA & LTA & PCR & GDP & IR \\
\hline GNGA & 1.00000 & & & & & & \\
NNNA & $\mathbf{0 . 7 1 0 8 4 1}$ & 1.00000 & & & & & \\
NNTA & $\mathbf{0 . 6 3 2 1 9 5}$ & 0.701184 & 1.00000 & & & & \\
LTA & $\mathbf{- 0 . 2 5 4 7 1 1}$ & -0.140006 & 0.059984 & 1.00000 & & & \\
PCR & $\mathbf{- 0 . 4 9 6 4 3 7}$ & $\mathbf{- 0 . 6 4 7 6 9 1}$ & $\mathbf{- 0 . 6 4 0 7 2 8}$ & 0.007225 & 1.00000 & & \\
GDP & 0.002897 & 0.012786 & 0.008301 & -0.002238 & -0.010083 & 1.00000 & \\
IR & $\mathbf{- 0 . 0 3 9 2 8 3}$ & 0.034701 & 0.011478 & 0.055684 & 0.039021 & -0.050197 & 1.00000 \\
\hline
\end{tabular}

\subsection{Testing for stationarity}

Stationarity has been tested to see whether the variables are mean reverting or not. According to Mahadeva and Robinson 2004, running an OLS on non-stationary data gives spurious regression results. However, a similar research conducted by Levin, Lin and Chu (2002) and Pesaran and shin (2003) tested the stationarity over the estimation period using LM unit root tests for balanced panels' series.

Accordingly, this research conducted an LM test and as per the summarized results exhibited in Table 5, independent and dependent variables of this study do not suffer any unit root problems at levels I (0) since null hypothesis of the variables named, Y, GNGA, NNNA, NNTA, LTA and PCR had been rejected at 5\% significant level and the null hypothesis of GDP and IR had been rejected at 1\% significant level. Hence, in general all variables are considered as mean reverting. 
Table 5: Summary Results of Unit Root Tests

\begin{tabular}{llll}
\hline \hline Variable & Levin, Lin, Chu Test & Pesaran, Shin Test & I(o) or I (I) \\
\hline Profitability (Y) & $0.0479^{*}$ & $0.0014^{*}$ & $\mathrm{I}(\mathrm{o})$ \\
GNGA & $0.0181^{*}$ & $0.0099^{*}$ & $\mathrm{I}(\mathrm{o})$ \\
NNNA & $0.0592^{*}$ & $0.0210^{*}$ & $\mathrm{I}(\mathrm{o})$ \\
NNTA & $0.0085^{*}$ & $0.0085^{*}$ & $\mathrm{I}(\mathrm{o})$ \\
LTA & $0.0510^{*}$ & $0.0012^{*}$ & $\mathrm{I}(\mathrm{o})$ \\
PCR & $0.0058^{*}$ & $0.0000^{* *}$ & $\mathrm{I}(\mathrm{o})$ \\
GDP & $0.0000^{* *}$ & $0.0000^{* *}$ & $\mathrm{I}(\mathrm{o})$ \\
IR & $0.0000^{* *}$ & $0.0000^{* *}$ & $\mathrm{I}(\mathrm{o})$ \\
\hline
\end{tabular}

$*$ Stationary at $5 \%$ significant level $\quad * *$ Stationary at $1 \%$ significant level

\subsection{Multiple regression estimation results}

This section shows the regression analysis of domestic bank's profitability and asset quality factors including some macro variables. Using a fixed affect random model, the regression model has been run using E-views 9 application (Table 6).

Table 6: Summary Results of Model I

\begin{tabular}{lccc}
\hline \hline Variable & Coefficient & Std. Error & Probability \\
\hline GNGA & -0.170118 & 0.079038 & 0.0322 \\
NNNA & -0.201021 & 0.109761 & 0.0680 \\
NNTA & -0.228048 & 0.134262 & 0.0904 \\
LTA & -0.018371 & 0.025105 & 0.4649 \\
PCR & 0.008508 & 0.008773 & 0.3329 \\
GDP & $2.95 \mathrm{E}-06$ & $4.35 \mathrm{E}-06$ & 0.4983 \\
IR & -0.003765 & 0.049520 & 0.9394 \\
R-squared & $\mathbf{0 . 2 1 5 7 7 6}$ & & \\
Adjusted R-squared & 0.197599 & & \\
Durbin-Watson stat & $\mathbf{0 . 5 3 6 7 0 2}$ & & \\
\hline
\end{tabular}

R-squared value ${ }^{12}$ is the statistical measure to find out how close the data are to the fitted regression line. It is also known as the coefficient of multiple determinations for multiple regression. In general, the higher the $\mathrm{R}$-squared $\left(\mathrm{R}^{2}\right)$, the better the model fits for data.

\footnotetext{
12 The coefficient of determination is denoted $\boldsymbol{R} 2$. It must be between 0 and 1 , and it measures the proportion of the total variation in $y$ that is accounted for by variation in the regressors.
} 
From an empirical researcher's viewpoint, high $\mathrm{R}^{2}$ values arise in the case of a spurious regression (Granger and Newbold, 1974). However, in the summary results of the regression model depicted in Table 6, $\mathrm{R}^{2}$ stood at the level of 0.215776 which is at Moderate level and accepted for this study.

According to Greene (2002), $\mathrm{R}^{2}$ will never decrease when another variable is added to a regression equation. Therefore, a solution is given by this for panel data regressions which have low $\mathrm{R}^{2}$, to establish this result by adding lag dependent variables.

Hence, this study used lag dependent variables for the regression model to determine the movements in the dependent variable.

\subsection{Testing for the Classical Assumptions (Robustness) of the Model}

\section{Hetroscedasticity}

The scatter graph of the residuals does not show any fanning out of errors when the value of $\mathrm{x}$ is increasing (Figure 5).

Figure 5: Scatter Plot of errors

RESID

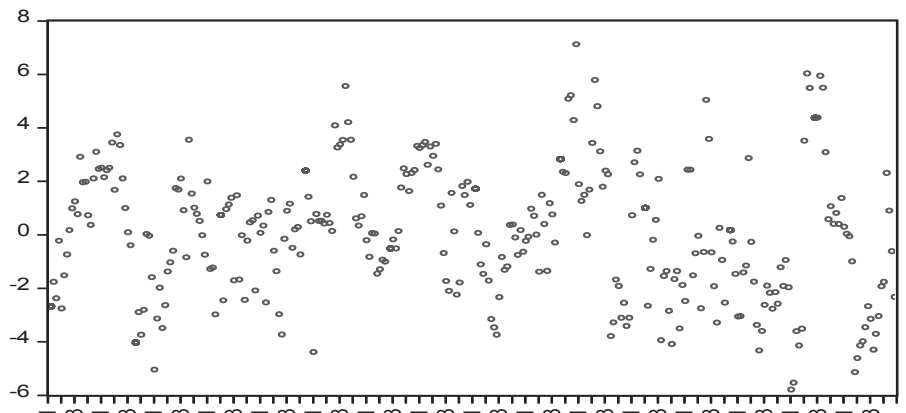

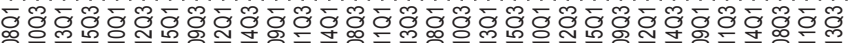

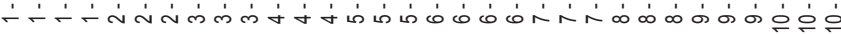

However, since it is unable to conclude whether the $\operatorname{Var}(\mathcal{E})=\sigma^{2}$ condition is satisfied, the Breusch-Pagan LM test for Heteroscedasticity was performed using the following hypothesis (Greene, (2002).

$\mathrm{H}_{0}=$ Model is homoscedastic

$\mathrm{H}_{1}=\mathrm{H}_{0}$ is not true 
Table 7: Results of Breusch-Pagan LM test

\begin{tabular}{lccc}
\hline \hline Test & Statistic & d.f. & Prob. \\
\hline Breusch-Pagan LM & 124.1971 & 45 & 0.0000 \\
Pesaran scaled LM & 8.348104 & & 0.0000 \\
Pesaran CD & -1.351489 & & 0.1765 \\
\hline
\end{tabular}

Null hypothesis is rejected at 1\% significant level and therefore, it is concluded that none of specification suffers from either Heteroscedasticity of the model (Table 7).

\section{Serial-correlation}

The Durbin Watson ${ }^{13}$ statistical test has been used to measure the autocorrelation in the residuals. The Durbin-Watson statistic always remains between 0 and 4. Durbin-Watson statistic of 2 means that there is no autocorrelation in the sample. Further, Greene (2002), mentions that the Durbin-Watson ratio is a clue to detect a nonsense regression where its value is low. As per Table 6 above, the Durbin-Watson value reported at a level of 0.536702 which is lower than the threshold around 2. Therefore, it can be concluded that the proposed model is suffering from an autocorrelation problem.

Balestra and Nerlove (1966), Fomby, Hill and Johnson (1984), Judge et al. (1985), Hsiao (1986), Anderson and Hsiao (1982), Nerlove (1971, 2003), and Baltagi (1995) also faced a similar kind of autocorrelation problem and by adding a lagged dependent variable to the model, the aforesaid studies overcome the autocorrelation.

Further, a solution was suggested by Wooldridge (2002) and Greene (2002) to overcome the autocorrelation of the problematic time series panel data, by running a Dynamic Panel Data Regression Model including the lag-dependent variables as the independent variable until the errors are minimised.

Based on the above literature and empirical studies, the panel regression model of this study was formulated as follows incorporating the lag dependent variable.

$$
\begin{aligned}
Y_{i t}= & Y_{i t-1}+\alpha+\beta_{1}(G N G A)_{i t}+\beta_{2}(N N N A)_{i t}+\beta_{3}(N N T A)_{i t}+\beta_{4}(L T A)_{i t}+ \\
& \beta_{5}(P C R)_{i t}+\beta_{6}(G D P)_{i t}+\beta_{7}(I R)_{i t}+\delta i+\gamma t+\varepsilon_{i t}
\end{aligned}
$$

\footnotetext{
13 Durbin's Test FD = the F statistic for the joint significance of $P$ lags of the residuals in the regression of the least squares residuals on $[\mathbf{x} t, y t-1, \ldots y t-R, e t-1, \ldots e t-P]$. Reject $H 0$ if $F D>F[P, T-K-P]$. This test examines the partial correlations between the residuals and the lagged residuals, controlling for the intervening effect of the independent variables and the lagged dependent variable (Greene, 2002).
} 
Accordingly, the summarized results are given at Table 8 below.

According to Table 8 below, the Durbin-Watson test statistics for serial correlation was shown as 2.053966 in Model II where, there is no significant autocorrelation among the successive values of the variables in the model. Hence, Model II is considered the best fitted model for this study.

\section{Interpretation of Results}

This study comprehensively analyses the determinants of assets quality and its impact on bank profitability. According to the empirical results as depicted in Table 8 , the highest $\mathrm{R}^{2}$ of 0.638057 is represented in Model II analysis. Hence, compared to Model I, R2 of 0.638057 of Model II indicates a high existence of correlation among $Y$ and GNGA, NNNA, NNTA, LTA, PCR, GDP and IR variables.

Table 8: Summary Results -Model II

\begin{tabular}{lcc}
\hline Variable & $\begin{array}{c}\text { Model II with Lag Y (-1) } \\
\text { Coefficient }\end{array}$ & Probability \\
\hline C & 3.404789 & 0.0115 \\
GNGA & -0.060678 & 0.2629 \\
NNNA & -0.043906 & 0.5595 \\
NNTA & -0.084542 & 0.3572 \\
LTA & -0.004016 & 0.8145 \\
PCR & 0.006039 & 0.3127 \\
GDP & $-6.37 \mathrm{E}-06$ & 0.0327 \\
IR & -0.041854 & 0.2160 \\
Y (-1) & 0.719741 & 0.0000 \\
& & \\
R-squared & 0.638057 & \\
Adjusted R-squared & 0.628437 & \\
Durbin-Watson Statistics & $\mathbf{2 . 0 5 3 9 6 6}$ & \\
\hline
\end{tabular}

Similarly, the co-efficient of determination value $\left(\mathrm{R}^{2}\right)$ of 0.638057 indicates that about 63 per cent of variation of $Y$ can be explained by the combined influence of GNGA, NNNA, NNTA, LTA, PCR, GDP and IR variable. Hence, the null hypothesis of this study which predicted that "there is no relationship between the asset quality variables and bank's profitability" is rejected. 
The Table 2 depicts the five internal determinants of a bank's assets quality that have been used in this study. However, the results show that three determinants, GNGA, NNNA and NNTA are negatively related to a bank's profitability at an insignificant level that contradicts the literature. According to the coefficients of GNGA, NNNA and NNTA, at $1 \%$ change in these variables, a bank's profitability may be affected by $0.06 \%, 0.04 \%$ and $0.08 \%$ respectively. Khalid (2012), Kosmidou (2008) and Festus Nzoka (2015) also found the same relationship for banks in India, Greece and Kenya respectively at different significant levels.

GNGA indicates a bank's aggressiveness in lending and the credit risk of the bank. NNNA and NNTA show the same trend as well as GNGA. Achou and Tenguh (2008) in their study found that the lower the ratio the better and these variables are important in determining the profitability of banks because if banks do not effectively manage these risk factors, such profits would be unstable. According to the empirical results of this study, the same negative relationships of GNGA, NNNA and NNTA are found and it suggests that high assets quality/effective credit risk management results in lower cost of recovery, low NPA provisioning, which is less threatening to liquidity and high profitability. These results are consistent with previous findings by Kosmidou (2008) and Festus Nzoka (2014).

The literature identifies that high loan growth often assumes lower profit due to high credit risk, but there is also a high return as the loans have a greater expected return than other assets, such as government securities (Hempel et al., 1994). This statement is further supported by Abata (2014), where his study showed a significant positive relationship between loans to asset ratio and bank profit. However, the empirical results of this study show a $0.004 \%$ negative impact on bank profitability at a 1\% change in LTA at an insignificant level. This may be due to banks rapidly increasing their loan portfolio and having to pay a higher cost of funding and thereby, showing an inconsistency with the empirical findings of this study and the findings by Abata (2014).

Inflation is associated with higher costs and it could affect in two ways (Guru et al (2002), Jiang et al (2003) and Abreu and Mendes (2000). One would be to expect a negative relationship between inflation and bank profits since low inflation stabilizes the economy and it could improve the bank's profit due to low NPAs. Other would be to expect a positive relationship since in a high inflation scenario, banks might be encouraged to finance in property markets as an investment strategy that may lead to market losses.

Angela Roman (2003) and Abreu and Mendes (2000) found a strong negative relationship in Romania between IR and bank profit. Even though the said research showed a substantial effect on inflation in solvency of banks, a negative relationship between IR and a bank's profit was also evident at an insignificant level where $1 \%$ change in IR affects the bank's profit by only $0.04 \%$. 
In the Sri Lankan context, fluctuations in inflation affect the change in the bank's interest rates as well as profit margins. In such a situation, monetary policy involves stabilizing the economy that may result in a weak negative relationship between the variables.

Further, the empirical results illustrate that only one macroeconomic variable is significant in illuminating the bank profitability in Sri Lanka at 5\% significant level. However, this study suggests a significant negative relationship between GDP and bank profitability where a 1\% change in GDP has a 6.37E06\% impact on profitability. The results differ from the similar researches conducted by, Demirguc-Kunt and Huizinga (2000), Michael et at (2006), Athanasoglou et al (2008) and Khalid (2012) that point out a positive relationship between GDP growth and bank profitability, as a general increase in economic growth leads to an increased demand for credit allowing banks to increase their charges thereby increasing profitability.

However, the coefficient may also be negative as countries with higher GDP are assumed to have a banking system that operates in a mature environment resulting in with a more competitive interest and profit margins (Goldberg and Rai, 1996). These data have been obtained from national statistics published in the IMF's International Financial Statistics.

Further, the Growth rate of GDP affects the supply and demand for loans and deposits of the banks. A bank's profitability may be driven by real GDP for a number of reasons. First, a bank's assets quality will depend on the position of economic cycles. In economic upturns, low NPAs and high bank profits can be expected than in economic downturns. Therefore, a bank's profitability will be positively correlated with GDP growth. Secondly, GDP can affect the market size. In an upturn, there will be a higher demand for bank loans than in a downturn. Hence, higher demand for loans will result in higher profits for banks.

However, as in the case of this study, the coefficient of GDP may also be negative in some situations due to less demand for loans even in an economic upturn where high interest cost is charged by the banks that may lead to high profits margins.

\section{Conclusion}

This paper attempts to estimate the impact of asset quality factors on bank profitability using two macroeconomic variables. A multiple regression model was used in estimating the coefficient of the model. Based on the results of estimations and robustness tests carried out, it can be concluded that there is a positive relationship between assets quality and a bank's profitability. Even though previous literature has showed a strong relationship between the assets quality variables and a bank's profitability, this research confirms that the relationship between assets quality and bank profitability is at an insignificant level. Limitation on sample and data mainly affected to weaken the significance level of the repressors of this study. 


\section{Policy Implications, Limitations and Future Research}

From the policy maker's point of view, the regulator's recommendation to banks is to maintain quality assets in the bank balance sheet in order to ensure the operational efficiency of the bank in the short-term and enhance sustainability in long-run. Hence, findings of this study do not boost the outcome of other similar research findings conducted by Demirguc- Kunt and Huizinga (2000), Michael et at (2006), Athanasoglou et al (2008) and Khalid (2012).

Improper assets quality reduces bank profitability by increasing non-performing loans which may eventually lead to financial distress. As a result, banks need to make efforts to improve their financial soundness by following policy decisions;

a) Use collateral as security when granting loans to reduce further incidence of bad debts.

b) Implement better credit risk assessment indicators to overcome high credit risk that is involved in lending.

c) Ensure continuous post sanction risk monitoring over doubtful debts.

The scope of this study limited to 9 commercial banks and financial information only of 9 years due to the non availability of data. Therefore, further improvement can be made to this research by increasing the sample size, number of observations and incorporating macroeconomic variables such as interest rate and exchange rate fluctuations, thereby opening up avenues for future research in Sri Lanka for a better explanation for proxies in estimating the impact of assets quality. 


\section{References}

Abata, M. A., “Assets Quality and Bank Performance”, Research Journal of Finance and Accounting, Volume 5, 2014

Abreu, M., and Mendes, V., "Commercial Bank Interest Margins and Profitability”, Evidence for some EU Countries- Preliminary Draft, 2000

Achou, F. T., and Tegnuh, N. C., "Bank Performance and Credit Risk Management", University of Skovde Press, 2008

Adhikary, B. K., "Nonperforming loans in the banking sector of Bangladesh: Realities and challenges", Bangladesh Institute of Bank Management, 2006

Albertazzi, U., and Gambacarta, L., "Bank Profitability and Business Cycle”, Journal of Financial Stability, 2009

Athansasoglou, P., Brissimis, S. \& Delis, M., "Bank Specific, Industry Specific and Macroeconomic Determinants of Bank Profitability", Journal of International Financial Markets, Institutions and Money, 2008

Basle Committee on Banking Supervision, “Core Principles to Effective Banking Supervision”, 1997

Bikker, J. A., and Hu, H., "Cyclical Patterns in Profits Provisioning and Lending of Banks", GNB Staff Report 86/2002, 2002

Eze, G. P., \& Ogbulu, O. M., “Asset Quality Management and the Performance of Deposit Money Banks in Nigeria: A Co-integration and Variance Decomposition Analysis", International Journal of Economics and Financial Research, 2016

Festus K., Nzoka., “The Effect of Assets Quality on the Financial Performance of Commercial Banks in Kenya", 2014

Greene, Models for panel data, E book, 2002

Gujarati, Basic Econometrics, Fifth Edition, 2004

Guru, B. J., Staunton and B. Balashanmugam., "Determinants of Commercial Bank profitability in Malaysia", University Multimedia Working Paper, 2002

Hempel, G., H., Simonson, D. G., \& Coleman, Bank Management. 4th edition, New York, 1994

Jiang, G. N., Tang, E. Law and A. Sze., "Determinants of Bank Profitability in Hong Kong", Hong Kong Monetary Authority Research Memorandum, 2003 
Khalid, A. C., "The Impact of Assets Quality on Profitability of Private Banks in India", Journal of African Macroeconomics Review Vol 2, 2012

Kosmidou, K., Pasiouras, F. \& Floropoulos, J., "Linking profits to asset-liability management of domestic and foreign Banks in the UK", Applied Financial Economics, 2004.

Kunt, A. D., and Huizinga, H., "Financial Structure and Bank Profitability", Research Articles World Bank, 2000

Mahadeva, L., and Robinson, P., Hand book in Central Banking unit root test to belp model building, Bank of England, 2004

Nagle R., "Bank consolidation in to the twenty first century", Bankers magazine, 1991.

Ombaba, k. B., Mwengei., "Assessing the factors contributing to non-performing loans", Journal of Business \& Management, 2013

Rajaraman, B., and Bhatia, N., "NPA Variation across Indian Commercial Banks", Economic and Political weekly, 1999

Rajaraman, I., and Vasishstha, G. "Non-Performing Loans of Public Sector Banks", Economic and Political Weekly, 2002

Ranjan, R., and Sarath C,. "Non-Performing Loan and Terms of Credit of Public Sector Banks in India", Reserve Bank India, 2003

Sinha, P. and Sharma, S., "Determinants of Bank Profits and its Persistence in Indian Banks", Retrieved from bttp:/ / mpra.ub.uni-muenchen.de/61378/, 2014

Streeter, W., “Top Issues \& Trends”, ABA Banking Journal, 2000

Vighneswara, Swamy., "Modeling Bank Assets Quality and Profitability", E-Journal, 2015

Wasiuzzaman, S., and Ahmed T., "Profitability of Islamic Banks in Malaysia", Journal of Islamic economics, 2010

Whalen, G., “A Proportional Hazards Model of Bank Failure”, Economic Review, Federal Reserve Bank of Cleveland, 1991

Yin, N. P., "Look at Taiwan's Banking Problems from Asian Finance Crisis”, Banking Finance Magazine, 1999 


\section{Appendices}

A.1

Figure A1: Behaviour of Data
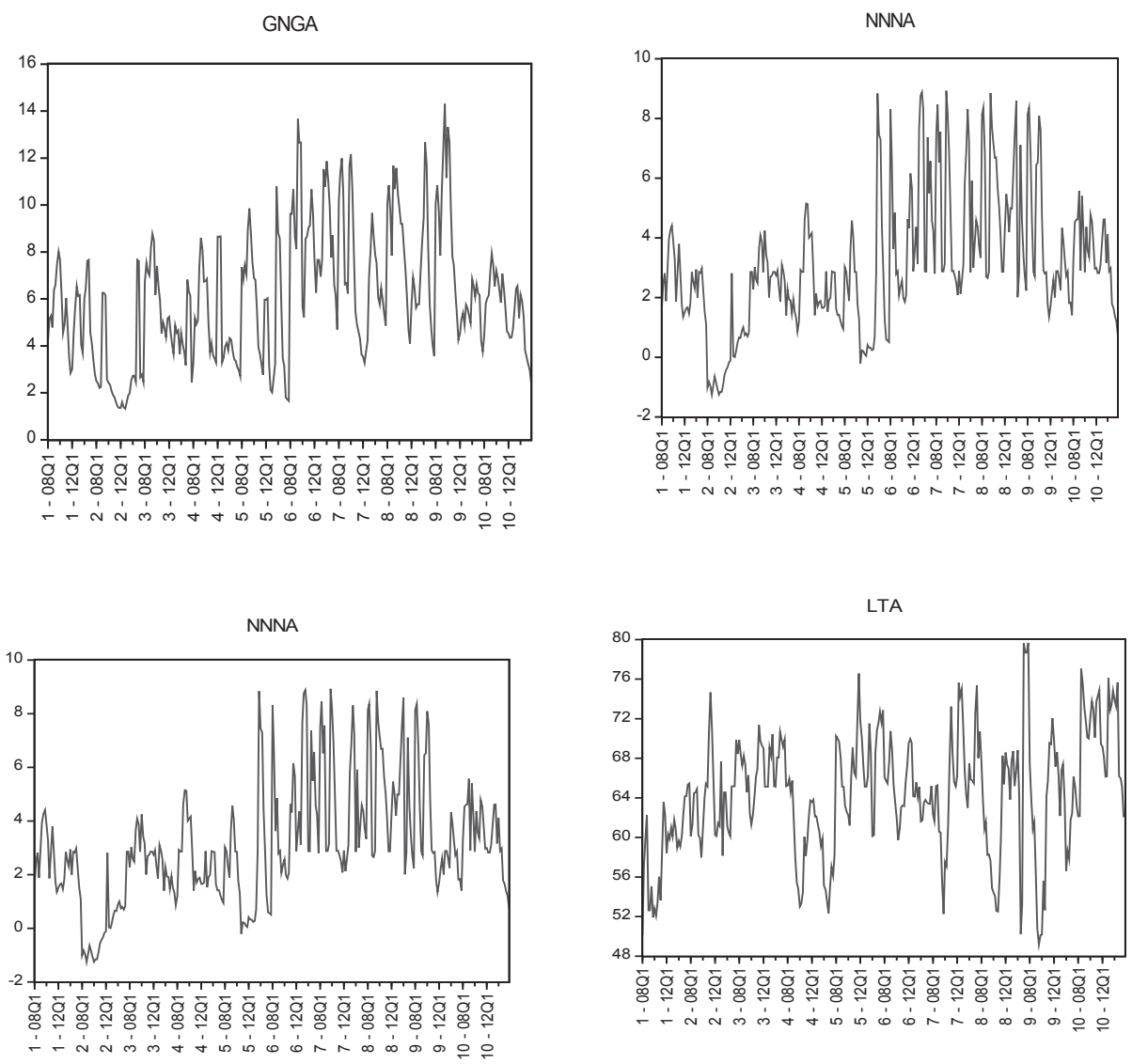

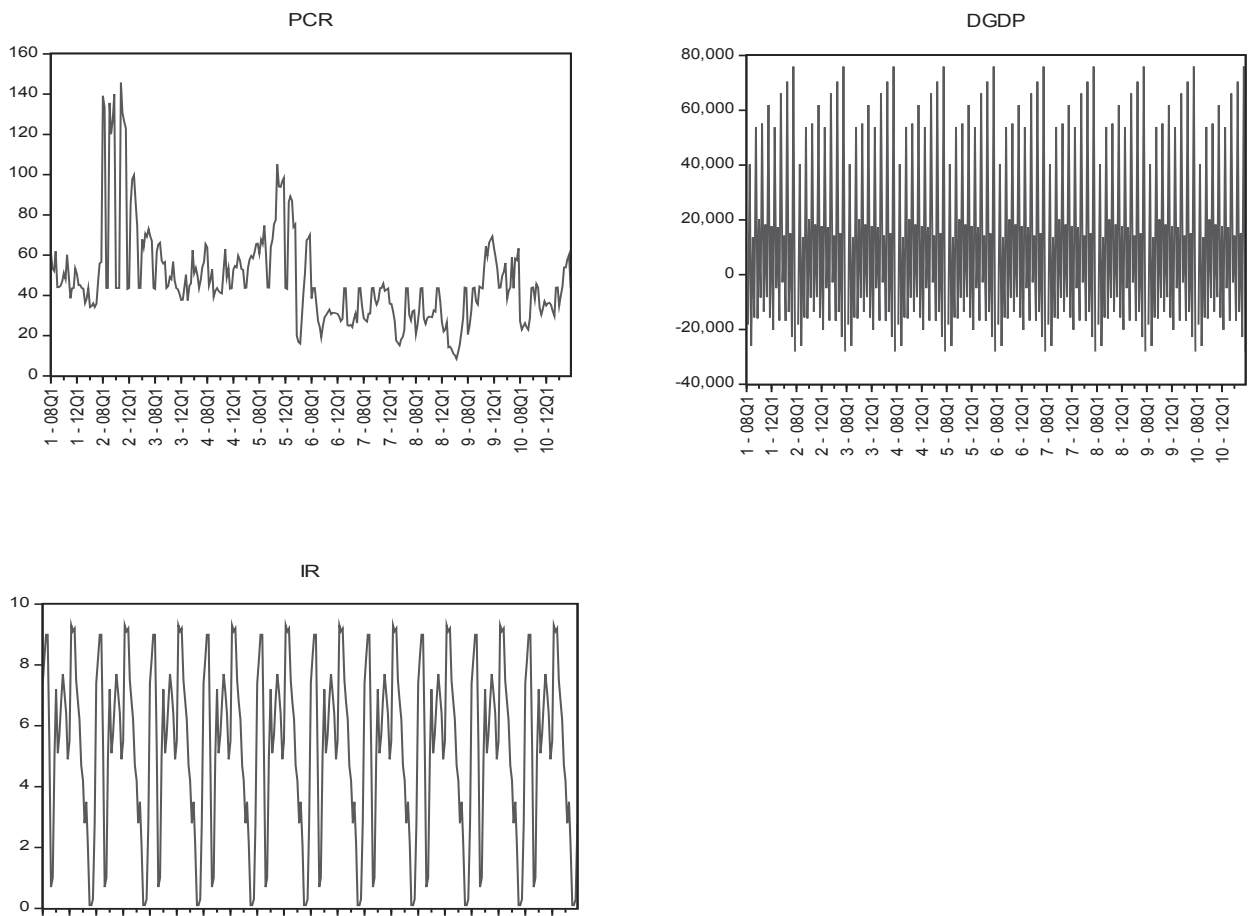

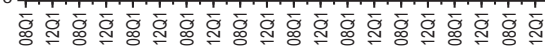

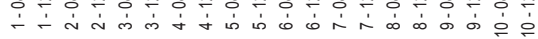

